\title{
Physical Attributes of Kaolinitic and Oxidic Oxisols Resulting from Different Usage Systems
}

\author{
José Frederico Centurion $^{1 *}$, Amauri Nelson Beutler ${ }^{1}$ and Zigomar Menezes de Souza ${ }^{1}$ \\ ${ }^{I}$ Universidade Estadual Paulista (UNESP/FCAV); Departamento de Solos e Adubos; Via de Acesso Rod. Paulo \\ Donato Castellani, s/n; Jaboticabal - SP - Brazil
}

\begin{abstract}
The objective of this study was to assess the physical attributes of a kaolinitic oxisol, medium texture (Haplustox) and an oxidic oxisol, clayey (Eutrustox) under different usage systems, localized in the region of Jaboticabal, SP, Brazil. The usage systems were sugarcane, cotton and forest. Parameters such as soil bulk density, total porosity, macro and microporosity at the depths of 0.0-0.1; 0.1-0.2; 0.2-0.3, and 0.3-0.4 m were evaluated. Haplustox showed greater bulk density and smaller total porosity, macro and microporosity. The usage increased the bulk density in 0.0-0.3 m depth, with greater effects on the kaolinitic oxisol, mainly in 0.1-0.2 m depth in the areas cultivated with sugarcane.
\end{abstract}

Key words: Sugarcane, cotton, forest, mineralogy, porosity, bulk density

\section{INTRODUCTION}

Soils have structural differences that originated from pedogenesis. Soils have different granulometric, mineralogic and organic matter compositions that can be modified by the usage and tillage of those soils. Ferreira et al. (1999a, 1999b) found that oxisols with kaolinitic clay fractions led to the development of a block-type macrostructure that caused the formation of oxisols with greater bulk densities and greater proportion of small pores. They also reported that oxisols with oxidic mineralogy formed porousstructures with lower bulk densities due to larger diameter pore spaces. Moreover, Chagas et al. (1997) reported that soil with a higher content of kaolinite in the clay fraction had a greater bulk density, lower total porosity and macroporosity when compared to other oxidic soils.
Excessive soil preparation, removal of growing plants from the surface and the establishment of annual crops combined with inappropriate tillage practices cause a disturbance in the balance between the soil and environment, by modifying its physical, chemical and biological attributes; by limiting its agricultural usage, and by making it more susceptible to erosion and degradation.

There are several studies on the effects of different usage and tillage systems on the physical properties of soils. Overall, data show an increase in soil bulk density and a decrease in porosity when soils are submitted to different usage systems when compared to its natural state (Hill et al., 1985; Cavenage et al., 1999; Beutler et al., 2001). Carvalho et al. (1991) evaluated the effect of many years of conventional cultivation with sugarcane and observed that soils with longer cultivation times had a decrease in the porosity especially in the macroporosity. Cerri et al. (1991)

\footnotetext{
${ }^{*}$ Author for correspondence
} 
reported that intensive cultivation of the soil with sugarcane had structural changes, mainly in the soil surface layers. Later studies conducted by Carvalho (1999) showed that conventional tillage systems followed by maize and sugarcane cultivation caused degradation of the physical attributes of the soil when compared to the natural state. This degradation was quantified through greater values of bulk density and microporosity, and lower values for macroporosity and total porosity.

The decrease of total porosity and macroporosity, with an increase in microporosity and soil bulk density in areas cultivated with annual crops, was mainly due to the intensive soil mixing during the preparation activities (Silva et al., 1986). Data collected by Machado et al. (1981) showed that the changes in the physical attributes of the oxisol soil cultivated with conventional tillage were also associated with decrease in organic matter content when compared to the natural state of the soil.

Even though Brazilian soils are mainly oxisols and are widely used for agriculture, little is known about the differences on the physical attributes between kaolinitic and oxidic oxisols soils under different usage systems. Therefore, the objective of this study was to evaluate the physical attributes of kaolinitic oxisol (Haplustox) and oxidic oxisol (Eutrustox) under different usage systems.

Table 1 - Physical and chemical attributes of Haplustox and Eutrustox for the usage systems, at four different depths

\begin{tabular}{|c|c|c|c|c|c|c|c|c|}
\hline \multirow{2}{*}{ Soil } & \multirow{2}{*}{ Use } & Clay & Silt & $\mathbf{F S}^{1}$ & $\mathbf{C S}^{2}$ & $\mathbf{O M}^{3}$ & $\mathrm{Fe}_{2} \mathrm{O}_{3}$ & $\mathbf{A l}_{2} \mathbf{O}_{3}$ \\
\hline & & \multicolumn{7}{|c|}{................................................. $\mathrm{g} \mathrm{kg}^{-1}$} \\
\hline & & & & $\mathbf{0 . 0}$ & & & & \\
\hline \multirow[t]{3}{*}{ Haplustox } & Sugarcane & 191 & 102 & 363 & 344 & 20 & 52 & 80 \\
\hline & Cotton & 226 & 77 & 349 & 348 & 18 & 57 & 110 \\
\hline & Forest & 178 & 115 & 363 & 344 & 47 & 57 & 120 \\
\hline \multirow[t]{4}{*}{ Eutrustox } & Sugarcane & 450 & 300 & 190 & 60 & 28 & 279 & 240 \\
\hline & Cotton & 420 & 340 & 170 & 70 & 23 & 260 & 220 \\
\hline & Forest & 330 & 330 & 230 & 110 & 66 & 262 & 120 \\
\hline & \multicolumn{8}{|c|}{0.1 - 0.2 m } \\
\hline \multirow[t]{3}{*}{ Haplustox } & Sugarcane & 235 & 83 & 332 & 350 & 19 & 49 & 90 \\
\hline & Cotton & 219 & 88 & 344 & 349 & 16 & 57 & 105 \\
\hline & Forest & 232 & 100 & 325 & 343 & 36 & 57 & 120 \\
\hline \multirow[t]{4}{*}{ Eutrustox } & Sugarcane & 460 & 290 & 180 & 70 & 23 & 280 & 230 \\
\hline & Cotton & 410 & 350 & 170 & 70 & 25 & 270 & 220 \\
\hline & Forest & 370 & 320 & 230 & 80 & 33 & 288 & 150 \\
\hline & \multicolumn{8}{|c|}{$0.2-0.3 \mathrm{~m}$} \\
\hline \multirow[t]{3}{*}{ Haplustox } & Sugarcane & 276 & 66 & 340 & 318 & 15 & 64 & 95 \\
\hline & Cotton & 249 & 77 & 337 & 337 & 13 & 73 & 105 \\
\hline & Forest & 275 & 66 & 341 & 318 & 26 & 60 & 115 \\
\hline \multirow[t]{4}{*}{ Eutrustox } & Sugarcane & 530 & 220 & 190 & 60 & 14 & 284 & 245 \\
\hline & Cotton & 460 & 300 & 180 & 60 & 21 & 262 & 235 \\
\hline & Forest & 470 & 230 & 230 & 70 & 26 & 287 & 175 \\
\hline & \multicolumn{8}{|c|}{$0.3-0.4 \mathrm{~m}$} \\
\hline \multirow[t]{3}{*}{ Haplustox } & Sugarcane & 305 & 63 & 327 & 305 & 13 & 51 & 105 \\
\hline & Cotton & 271 & 89 & 339 & 301 & 10 & 59 & 115 \\
\hline & Forest & 324 & 52 & 324 & 300 & 24 & 69 & 115 \\
\hline \multirow[t]{3}{*}{ Eutrustox } & Sugarcane & 560 & 220 & 160 & 60 & 16 & 298 & 250 \\
\hline & Cotton & 470 & 290 & 170 & 70 & 27 & 280 & 235 \\
\hline & Forest & 500 & 230 & 220 & 50 & 16 & 296 & 210 \\
\hline
\end{tabular}

Fine sand; ${ }^{2}$ Coarse sand; ${ }^{3}$ Organic matter

\section{MATERIALS AND METHODS}

The experiment was carried out in a kaolinitic oxisol, medium texture (Haplustox), and in oxidic oxisol, clayey (Eutrustox). Geographic co-ordinates of the experimental area were south latitude $21^{\circ} 08^{\prime} 27^{\prime \prime}$ and west longitude $48^{\circ} 16^{\prime} 17^{\prime}$, located in Jaboticabal, São Paulo state, Brazil. The weather is classified as mesothermic with dry winters (Cwa) by the Köppen system. The physical and chemical characterizations of the soils are shown in Table 1. 
Usage systems were sugarcane $\left(5^{\text {th }}\right.$ year $)$, cotton $\left(1^{\text {th }}\right.$ year) and forest. In the area cultivated with sugarcane for 30 years, practices such as conventional tillage using discs plow, harrow and chisel plow and burning were performed before cutting. The area cultivated with cotton was prepared by using discs plow, harrow and four leveler harrowings, and had been cultivated for 30 years with annual crops.

Disturbed and undisturbed samples were collected at $0.0-0.1 ; 0.1-0.2 ; 0.2-0.3$, and 0.3-0.4 m depths. The undisturbed samples collected with volumetric rings of 0.048 diameter and $0.03 \mathrm{~m}$ high were used to determine the following: bulk density according to Blake and Hartge (1986); microporosity by drying (0.006 $\mathrm{MPa})$ in a Richard pressure chambers with porous plate (Klute, 1986), and total porosity according to Danielson and Sutherland (1986). The macroporosity was obtained by the difference between total porosity and microporosity.

Particle size composition was established in disturbed samples through dispersion with water and $\mathrm{NaOH}\left(0.1 \mathrm{~mol} \mathrm{~L}^{-1}\right)$ and slow shaking for 16 hours, and the clay portion was determined by pipetting method according to Day (1965). Organic matter was determined by the method described by Raij et al. (1987). $\mathrm{Fe}_{2} \mathrm{O}_{3}$ and $\mathrm{Al}_{2} \mathrm{O}_{3}$ were determined through sulfuric agents according to Lim and Jackson (1986).

Experimental design was entirely randomized with subdivided parcels, with seven replications each. The effects of the usage systems on the soils physical attributes at different depths were verified by the variance analysis and significant means were compared by Tukey test at the 0.05 probability level.

\section{RESULTS AND DISCUSSION}

Since variance analysis did not reveal significant interactions between soils vs. usage systems, are shown in the means of usage systems by depths for both soils (Figure 1). Haplustox showed significantly higher bulk density, and lower total, macro and microporosity. The highest soil bulk density and lowest total porosity, macro and microporosity were due to the lowest oxide contents of $\mathrm{Fe}$ and $\mathrm{Al}$ and coarser granulometry (Table 1). However, soils with coarse granulometry provided porous formation with greater diameter, resulting in a greater macroporosity. These traits were not observed in this study. This probably was due to the fact that the mineralogy of the kaolinitic clay fraction of Haplustox led to the formation of compact block structures (Ferreira, 1999a). The greater values for bulk density, lower total porosity and macroporosity in kaolinitic soils when compared to oxidic soils agree with studies conducted by Chagas et al. (1997) and Ferreira et al. (1999b) in soils with similar granulometric composition.

According to Ferreira et al. (1999a), soils with predominantly kaolinite in the clay fraction presented small subangular block structures which combined with other soil aspects to form pores that were predominantly cavities due to the face to face adjustment of the kaolinite plates, thus resulting in greater bulk density and smaller diameter pores. These authors also found that the oxidic mineralogy of the clay fraction promoted the formation of round microaggregates $(<1 \mathrm{~mm})$ that were predominately composed of porous packages around the microaggregates, which formed granular macrostructures with a porous appearance "in situ" that promoted the formation of a greater quantity of a large porous and lower bulk density. Demattê (1988) documented that the formation of very stable sand-silt size aggregates occured in oxidic soil due to both, clay content and cementing elements, or to the actions of iron and aluminum oxides. Pinheiro-Dick and Schwertmann (1996) reported that hematite and goethite form homogeneous microaggregates with gibbsite, kaolinite and quartz, thus promoting greater porosity when comparing to kaolinitic soils.

The only parameter that did not differ between the soils was the macroporosity in $0.0-0.1 \mathrm{~m}$ depth (Figure 1). This was due to the changes in the structure related to the soil usage, which affected mainly the surface layer and was possibly more extensive in the more compact Haplustox. Moreover, macroporosity is a physical attribute that reflects small changes in structure when compared to the total porosity and microporosity, thus confirming the results obtained by Hill et al. (1985), Bertol (1989), Carvalho et al. (1991) and Beutler et al. (2001).

Correlation between $\mathrm{Fe}$ and $\mathrm{Al}$ oxides and the soil physical attributes have shown a negative relationship with soil bulk density and positive relationship with microporosity and total porosity (Table 2), confirming the studies conducted by Chagas et al. (1997) and Ferreira et al. (1999b). 
However, Ferreira et al. (1999b) found a stronger effect of $\mathrm{Al}$ oxides on the physical attributes, which was probably not observed in this study due to the contents of iron oxides being slightly greater than the aluminum oxides.
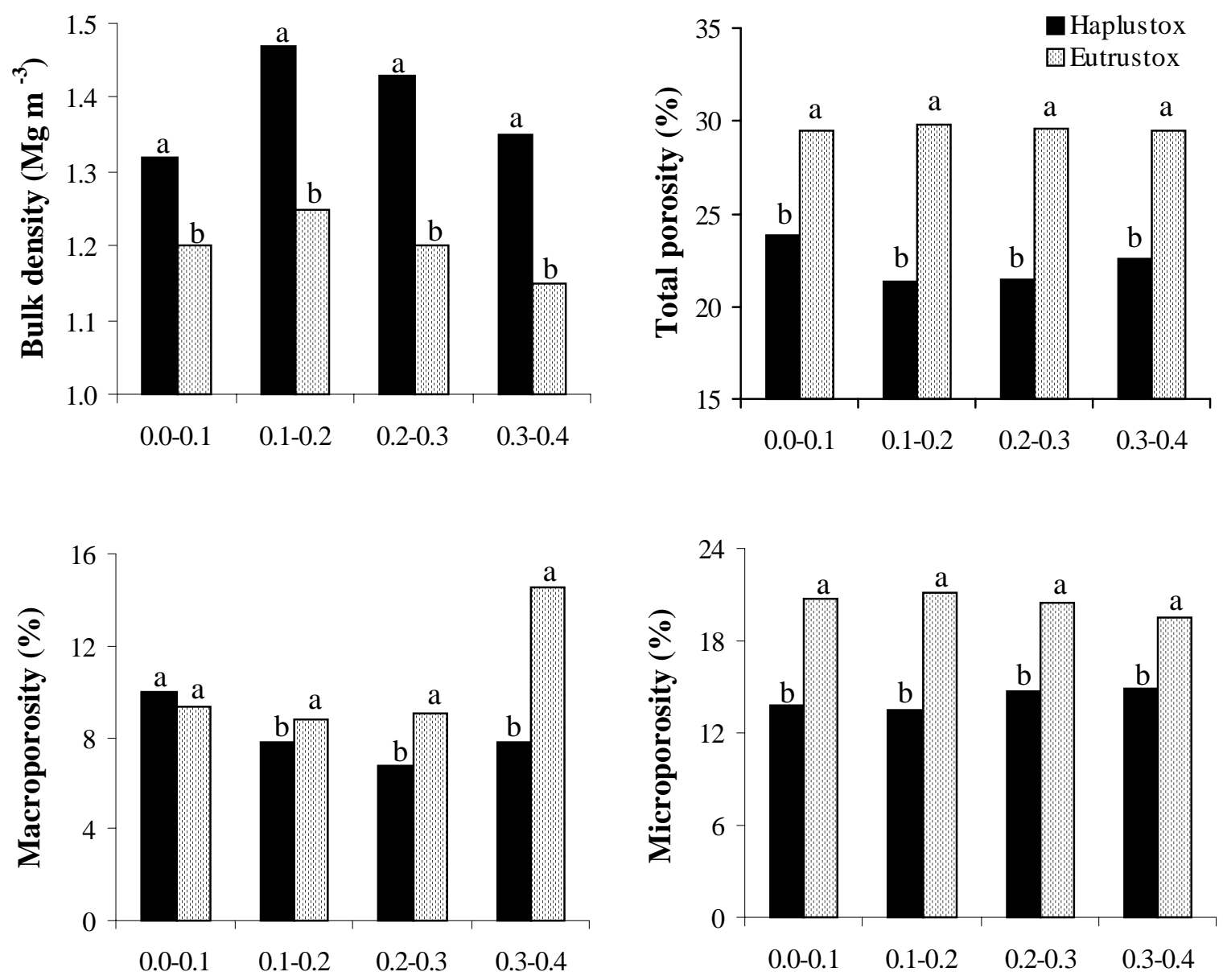

Depth (m)

Figure 1 - Physical attributes of Haplustox and Eutrustox at different depths.

Table 2 - Correlations between the $\mathrm{Fe}_{2} \mathrm{O}_{3}$ and the $\mathrm{Al}_{2} \mathrm{O}_{3}$ in physical attributes

\begin{tabular}{ccccc}
\hline & \multicolumn{3}{c}{ Correlation } \\
\cline { 2 - 5 } & Bulk density & Total porosity & Macro porosity & Micro porosity \\
\hline $\mathrm{Fe}_{2} \mathrm{O}_{3}$ & $0.52^{* *}$ & $0.80^{* *}$ & $0.16^{\mathrm{NS}}$ & $0.79^{* *}$ \\
$\mathrm{Al}_{2} \mathrm{O}_{3}$ & $0.43^{*}$ & $0.69^{* *}$ & $-0.03^{\mathrm{NS}}$ & $0.88^{* *}$ \\
\hline
\end{tabular}

** Significant at 1\%; * Significant at 5\%; ${ }^{\text {NS }}$ Not significant

The effects of soil usage on the physical attributes were different in Haplustox (Table 3 ) in relation to Eutrustox (Table 4). Haplustox soil under cotton cultivation had greater bulk density in the 0.0-0.1 $\mathrm{m}$ depth when compared with sugarcane cultivation. This was caused by the intensive preparation of the soil using discs plow, harrow and four leveler harrowings in cotton, which pulverized the soil more at this depth when compared to sugarcane, which are cultivated every 
five years. Carvalho Filho (1999) did not find significant difference for soil density in the area cultivated with maize and sugarcane in oxidic oxisol, where the soil preparation for maize cultivation was less intense compared to cotton with only harrowings.

Table 3 - Physical attributes of Haplustox under different usage systems at four different depths

\begin{tabular}{|c|c|c|c|c|}
\hline Use & $\begin{array}{c}\text { Bulk density } \\
\mathrm{Mg} \mathrm{m}^{-3}\end{array}$ & $\begin{array}{r}\text { Total porosity } \\
\end{array}$ & (.................................... \% & Microporosity \\
\hline \multicolumn{5}{|c|}{$0.0-0.1 \mathrm{~m}$} \\
\hline Sugarcane & $1.40 \mathrm{Bc}$ & $22.22 \mathrm{Ba}$ & $8.72 \mathrm{Ba}$ & $13.50 \mathrm{ABb}$ \\
\hline Cotton & $1.64 \mathrm{Aa}$ & $17.66 \mathrm{Cb}$ & $2.90 \mathrm{Cb}$ & $14.75 \mathrm{Aa}$ \\
\hline Forest & $0.93 \mathrm{Cb}$ & $31.70 \mathrm{Aa}$ & $18.52 \mathrm{Aa}$ & 13.19 Bab \\
\hline \multicolumn{5}{|c|}{$0.1-0.2 \mathrm{~m}$} \\
\hline Sugarcane & $1.59 \mathrm{Aa}$ & $19.45 \mathrm{Bb}$ & $5.15 \mathrm{Bb}$ & $14.30 \mathrm{Ab}$ \\
\hline Cotton & $1.60 \mathrm{Aa}$ & $18.66 \mathrm{Bb}$ & $4.38 \mathrm{Bab}$ & $14.28 \mathrm{Aa}$ \\
\hline Forest & $1.21 \mathrm{Ba}$ & $25.89 \mathrm{Ab}$ & $13.90 \mathrm{Ab}$ & $11.99 \mathrm{Bb}$ \\
\hline \multicolumn{5}{|c|}{$0.2-0.3 \mathrm{~m}$} \\
\hline Sugarcane & $1.52 \mathrm{Aab}$ & $20.95 \mathrm{Bab}$ & $5.10 \mathrm{Bb}$ & $15.85 \mathrm{Aa}$ \\
\hline Cotton & $1.59 \mathrm{Aa}$ & $19.17 \mathrm{Bb}$ & $3.59 \mathrm{Bb}$ & $15.58 \mathrm{Aa}$ \\
\hline Forest & $1.19 \mathrm{Ba}$ & $24.08 \mathrm{Ac}$ & $11.51 \mathrm{Ac}$ & $12.57 \mathrm{Bab}$ \\
\hline \multicolumn{5}{|c|}{$0.3-0.4 \mathrm{~m}$} \\
\hline Sugarcane & $1.46 \mathrm{Abc}$ & $21.44 \mathrm{Ba}$ & $5.59 \mathrm{Bb}$ & $15.85 \mathrm{Aa}$ \\
\hline Cotton & $1.41 \mathrm{Ab}$ & $21.54 \mathrm{Ba}$ & $6.63 \mathrm{Ba}$ & $14.90 \mathrm{ABa}$ \\
\hline Forest & $1.18 \mathrm{Ba}$ & $24.85 \mathrm{Abc}$ & $11.06 \mathrm{Ac}$ & $13.80 \mathrm{Ba}$ \\
\hline $\mathrm{CV}_{\mathrm{USE}}(\%)$ & 4.68 & 6.04 & 21.40 & 7.97 \\
\hline $\mathrm{CV}_{\text {DEPTH }}(\%)$ & 4.54 & 5.50 & 19.85 & 6.69 \\
\hline
\end{tabular}

Values with different capital letters in the columns (at the same depth) and values with different low case letters in the columns (between depths and same tillage) are significantly different at the 0.05 probability level

The lower bulk densities at 0.0-0.1 m depth under sugarcane and forest was due to the greater content of organic matter and not to soil preparation, which favored the biologic activity and soil structure. In the sugarcane area, a higher bulk density at $0.1-0.2 \mathrm{~m}$ depth was observed and this agrees with the studies done by Carvalho Filho (1999). According to Magalhães (1990), soils cultivated annually undergo successive processes of compaction, which begins with as a natural process or as a forced one, due to the traffic of agricultural machines and decompaction through plowing and harrowing.

The forested area showed the lowest bulk density at all depths and the density increased with depth. This was expected because it was a common behavior native conditions, which was caused by the decrease of organic matter content in depht and due the weight of the layers of soil above. These data agreed with the studies conducted by Cavenage et al. (1999). Greater density values in cultivated soils have been documented by several studies (Carvalho et al., 1999; Cavenage et al., 1999; Beutler et al., 2001).

Our results revealed that the increase in the soil bulk density caused a reduction in the macroporosity in all depths, thus confirming the data obtained by Bertol (1989), Cerri et al. (1991), Carvalho Filho (1999) and Beutler et al. (2001). Macroporosity is the first and most affected by the compaction process (Bertol, 1989). This study showed that the soil usage systems increased soil bulk density and decreased macroporosity and the total porosity in all analyzed depths when compared to those from native conditions.

Reduction in macroporosity with depth in the forest and sugarcane area is consistent with the decrease in the organic matter content with depth. Increases in the total porosity and soil macroporosity was observed in the area with cotton, in the Haplustox, as depth increases, and these were probably related to the intense surface traffic of machines and equipment during soil preparation and deep cultivation with agricultural 
implements. These had strong effects on the compaction of the surface layer when compared to that from the sugarcane area.

The microporosity for the forest soil was lower at all depth and did not increase with the density, while the macroporosity decreased in the usage systems. These data agreed with those documented by Bertol (1989), who found that macroporosity was initially affected by the increase of the bulk density followed by an increase in the microporosity. Similar results were reported by Secco et al. (1997), who observed differences in the oxisol bulk density and in the macroporosity when comparing usage systems, without significant alterations in the soil microporosity.

In Eutrustox (Table 4), the cotton area presented higher bulk density at all depths, followed by sugarcane. In oxidic oxisol, Carvalho (1999) did not find differences in the bulk density of the cultivated area with maize when compared to that with sugarcane, probably due to less machine operations performed during soil preparation. Cultivated soils showed greater densities at $0.0-0.3$ $\mathrm{m}$ depth, and these results associated with the turning of the soil at that this depth.

Table 4 - Physical attributes of Eutrustox under different usage systems at four different depths

\begin{tabular}{|c|c|c|c|c|}
\hline Use & $\begin{array}{c}\text { Bulk density } \\
\mathrm{Mg} \mathrm{m}^{-3} \\
\end{array}$ & \multicolumn{3}{|c|}{ 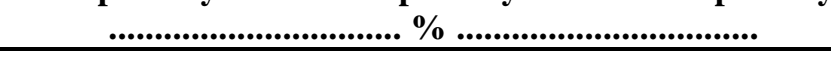 } \\
\hline & & $0.0-0.1 \mathrm{~m}$ & & \\
\hline Sugarcane & $1.21 \mathrm{Ba}$ & $29.22 \mathrm{Aa}$ & $7.25 \mathrm{Bb}$ & $21.96 \mathrm{Aa}$ \\
\hline Cotton & $1.34 \mathrm{Aab}$ & $28.44 \mathrm{Ba}$ & $6.02 \mathrm{Ba}$ & $22.42 \mathrm{Ab}$ \\
\hline \multirow[t]{2}{*}{ Forest } & $1.05 \mathrm{Cb}$ & $30.81 \mathrm{Aa}$ & $14.58 \mathrm{Aa}$ & $16.23 \mathrm{Ba}$ \\
\hline & & 0.1 - $0.2 \mathrm{~m}$ & & \\
\hline Sugarcane & $1.24 \mathrm{Ba}$ & $30.30 \mathrm{Aa}$ & $8.37 \mathrm{Bb}$ & $21.93 \mathrm{Ba}$ \\
\hline Cotton & $1.36 \mathrm{Aa}$ & $27.91 \mathrm{Ba}$ & $3.61 \mathrm{Cb}$ & $24.30 \mathrm{Aa}$ \\
\hline \multirow[t]{2}{*}{ Forest } & $1.15 \mathrm{Ca}$ & $31.25 \mathrm{Aa}$ & $14.25 \mathrm{Aa}$ & $17.00 \mathrm{Ca}$ \\
\hline & & $0.2-0.3 \mathrm{~m}$ & & \\
\hline Sugarcane & 1.16 Bab & $30.49 \mathrm{Aa}$ & $8.46 \mathrm{Bb}$ & $22.03 \mathrm{Aa}$ \\
\hline Cotton & $1.29 \mathrm{Aab}$ & $28.05 \mathrm{Ba}$ & 4.96 Cab & 23.10 Aab \\
\hline \multirow{2}{*}{ Forest } & 1.14 Bab & $30.23 \mathrm{Aa}$ & $13.81 \mathrm{Aa}$ & $16.42 \mathrm{Ba}$ \\
\hline & & $0.3-0.4 \mathrm{~m}$ & & \\
\hline Sugarcane & $1.10 \mathrm{Bb}$ & $29.87 \mathrm{Aa}$ & $11.25 \mathrm{Aa}$ & $18.61 \mathrm{Bb}$ \\
\hline Cotton & $1.26 \mathrm{Ab}$ & $28.24 \mathrm{Ba}$ & $5.53 \mathrm{Bab}$ & 22.71 Aab \\
\hline Forest & 1.10 Bab & $30.24 \mathrm{Aa}$ & $13.00 \mathrm{Aa}$ & $17.24 \mathrm{Ba}$ \\
\hline $\mathrm{CV}_{\text {USE }}(\%)$ & 5.43 & 4.09 & 19.18 & 6.96 \\
\hline $\mathrm{CV}_{\text {DEPTH }}(\%)$ & 5.21 & 4.91 & 17.64 & 6.43 \\
\hline
\end{tabular}

Values with different capital letters in the columns (at the same depth) and values with different low case letters in the columns, between depths, are significantly different at the 0.05 probability level.

Compact layers were not found in Eutrustox at 0.0-0.3 $\mathrm{m}$ depth, which resulted from soil preparation under improper conditions, as observed for sugarcane at $0.1-0.2 \mathrm{~m}$ depth in Haplustox. The lack of compact layers was due to the oxidic mineralogy of Eutrustox, which promoted the formation of very stable microaggregates (Demattê, 1988), thus making the soil resistant to compression. The greater soil bulk density in Eutrustox with cotton caused a decrease of the total porosity in all depths and the lowest macroporosity at $0.1-0.4 \mathrm{~m}$ depth. Total porosity in sugarcane and forested areas were not different, but the pores diameter differed, causing a decrease in the macroporosity in the area cultivated with sugarcane. Therefore, the effect of the usage systems on the soil structure was less of an influence on these soils.

Kaolinitic oxisol (Haplustox) showed the greatest bulk density and the smallest total porosity, macro and microporosity. Soil cultivation increased the bulk density and decreased total porosity at $0.0-0.3 \mathrm{~m}$ depth with intensive effects on Haplustox. Soil cultivated with sugarcane had compaction at 0.1-0.2 m depth in Haplustox, while cotton had greater bulk density at all depths in the Eutrustox. 


\section{RESUMO}

A mineralogia da fração argila e os sistemas de uso exercem fundamental importância na estrutura do solo. Assim, objetivou-se avaliar atributos físicos de um Latossolo Vermelho Distrófico, caulinítico (LVd), e, de um Latossolo Vermelho Eutroférrico, oxídico (LVef), sob diferentes sistemas de uso, localizados no município de Jaboticabal (SP), Brasil. Os sistemas de uso foram: cana-de-açúcar; algodão e mata. Foram avaliadas a densidade do solo, porosidade total, macro e microporosidade, nas profundidades de $0,0-0,1$, 0,1-0,2, 0,2-0,3, 0,3-0,4 m. O Latossolo caulinítico (LVd) apresentou maior densidade do solo e menor porosidade total, macro e microporosidade. $\mathrm{O}$ uso aumentou a densidade do solo na profundidade de 0,0-0,3 m, com efeitos maiores no Latossolo caulinítico, principalmente na profundidade de 0,1-0,2 $\mathrm{m}$ na área cultivada com cana-de-açúcar.

\section{REFERENCES}

Bertol, I. (1989), Degradação física do solo sob a cultura do alho. R. Agrop. Catarinense, 2, 47-50.

Beutler, A. N.; Silva, M. L. N.; Curi, N.; Ferreira, M. M.; Cruz, J. C. and Pereira Filho, I. A. (2001), Resistência à penetração e permeabilidade de Latossolo Vermelho distrófico típico sob sistemas de manejo na região dos cerrados. R. Bras. Ci. Solo, 25, 167-177.

Blake, G. R. and Hartge, K. H. (1986), Bulk density. In: Klute, A. (ed.). Methods of soil analysis. Madison : American Society of Agronomy. pp. 377-382.

Carvalho Filho, A. (1999), Levantamento detalhado e alterações de alguns atributos provocados pelo uso e manejo dos solos da Faculdade de Agronomia de Ituverava/SP. Msc Thesis, Universidade Estadual Paulista, Jaboticabal, Brasil.

Carvalho, E. J. M.; Figueiredo, M. S. and Costa, L. M. (1999), Comportamento físico-hídrico de um Podzólico Vermelho-Amarelo Câmbico fase terraço sob diferentes sistemas de manejo. R. Bras. Ci. Solo, 34, 257-265.

Carvalho, S. R.; Bruand, A.; Hardy, M.; Leprum, J. C. and Jamagne, M. (1991), Tassement des sols ferrallitiques Podzólico Vermelho Amarelo sous culture de canne à sucre (état de Rio de Janeiro, Brézil): apport d'une analyse de la porosité associée a une connaissance détaillée de la phase minérale. Cahiers Orstom, sér. Pedologie, 26, 195-212.
Cavenage, A.; Moraes, M. L. T.; Alves, M. C.; Carvalho, M. A. C.; Freitas, M. L. M. and Buzetti, S. (1999), Alterações nas propriedades físicas de um Latossolo Vermelho-Escuro sob diferentes culturas. R. Bras. Ci. Solo, 23, 997-1003.

Cerri, C. C.; Feller, C. and Chauvel, A. (1991), Evolução das principais propriedades de um Latossolo Vermelho-Escuro após desmatamento e cultivo por doze e cinqüenta anos com cana-deaçúcar. Cahiers Orstom, sér. Pedologie, 26, 37-50.

Chagas, C. S.; Curi, N.; Duarte, M. N.; Motta, P. E. F. and Lima, J. M. (1997), Orientação das camadas de rochas metapelíticas pobres na gênese de latossolos sob cerrado. Pes. Agropec. Bras., 32, 539-548.

Danielson, R. E. and Sutherland, P. L. (1986), Porosity. In: Klute, A. (Ed.). Methods of soil analysis. Madison : American Society of Agronomy. pp. 443-461.

Day, P. R. (1965), Particle fracionation and particle size analysis. In: Black, C. A. (Ed.). Methods of soil analysis. Madison : American Society of Agronomy. Part 1. pp. 545-567.

Demattê, J. L. I. (1988), Manejo de solos ácidos dos trópicos úmidos - região amazônica. Campinas : Fundação Cargill.

Ferreira, M. M.; Fernandes, B. and Curi, N. (1999a), Mineralogia da fração argila e estrutura de latossolos da região sudeste do Brasil. R. Bras. Ci. Solo, 23, 507-514.

Ferreira, M. M.; Fernandes, B. and Curi, N. (1999b), Influência da mineralogia da fração argila nas propriedades físicas de latossolos da região sudeste do Brasil. R. Bras. Ci. Solo, 23, 515-524.

Hill, R. L.; Horton, R. and Cruse, R. M. (1985), Tillage effects on soil water retention and pore size distribution of two Mollisols. Soil Sci. Soc. Am. J., 49, 1264-1270.

Klute, A. (1986), Water retention: laboratory methods. In: Klute, A. (Ed.). Methods of soil analysis. Madison : American Society of Agronomy. pp. 635-662.

Lim, C. H. and Jackson, M. L. (1986), Dissolution for total elemental analysis. In: Page, A. L. (Ed.). Methods of soil analysis. Madison : American Society of Agronomy. pp. 1-12.

Machado, J. A.; Souza, D. M. P. and Brum, A. C. R. (1981), Efeito de anos de cultivo convencional em propriedades físicas do solo. R. Bras. Ci. Solo, 5, 187-189.

Magalhães, P. S. G. (1990), Manejo de solo e seus efeitos sobre a compactação. Lav. Arroz., 43, 14-17.

Pinheiro-Dick, D. and Schwertmann, U. (1996), Microaggregates from Oxisols and Inceptisols: dispersion through selective dissolutions and physicochemical treatments. Geoderma, 74, 49-63.

Raij, B. van; Quaggio, J. A.; Cantarella, H.; Ferreira, M. E.; Lopes, A. S. and Bataglia, O. C. (1987), Análise química do solo para fins de fertilidade. Campinas : Fundação Cargill. 
Secco, D.; Da Ros, L. C. O.; Fiorin, J. E.; Pautz, C. V. and Pasa, L. (1997), Efeito de sistemas de manejo nas propriedades físicas de um Latossolo VermelhoEscuro. Ci. Rural, 27, 57-60.

Silva, A. P.; Libardi, P. L. and Camargo, O. A. (1986), Influência da compactação nas propriedades físicas de dois Latossolo. R. Bras. Ci. Solo, 10, 91-95.

Received: April 11, 2003;

Revised: August 27, 2003;

Accepted: January 28, 2004. 